\title{
Usage of Human Mesenchymal Stem Cells in Cell-based Therapy: Advantages and Disadvantages
}

\author{
Hee Jung Kim ${ }^{1}$ and ${ }^{\dagger}$ Jeong-Soo Park ${ }^{2}$ \\ ${ }^{1}$ Department of Physiology, Dankook University College of Medicine, Cheonan, Korea \\ ${ }^{2}$ Department of Biochemistry, Dankook University College of Medicine, Cheonan, Korea
}

\begin{abstract}
The use of human mesenchymal stem cells (hMSCs) in cell-based therapy has attracted extensive interest in the field of regenerative medicine, and it shows applications to numerous incurable diseases. hMSCs show several superior properties for therapeutic use compared to other types of stem cells. Different cell types are discussed in terms of their advantages and disadvantages, with focus on the characteristics of hMSCs. hMSCs can proliferate readily and produce differentiated cells that can substitute for the targeted affected tissue. To maximize the therapeutic effects of hMSCs, a substantial number of these cells are essential, requiring extensive ex vivo cell expansion. However, hMSCs have a limited lifespan in an in vitro culture condition. The senescence of hMSCs is a double-edged sword from the viewpoint of clinical applications. Although their limited cell proliferation potency protects them from malignant transformation after transplantation, senescence can alter various cell functions including proliferation, differentiation, and migration, that are essential for their therapeutic efficacy. Numerous trials to overcome the limited lifespan of mesenchymal stem cells are discussed.
\end{abstract}

Key words : Mesenchymal stem cell, Cell-therapy, Cellular senescence, Regenerative medicine

\section{INTRODUCTION}

Human mesenchymal stem cells (hMSCs) show promise in the field of regenerative medicine because they can modulate numerous incurable diseases. Mesenchymal stem cells, also called mesenchymal stromal cells, are a type of adult stem cell, that play a role in maintaining and repairing various adult tissues and organs (Pittenger et al., 1999). hMSCs have emerged as a promising candidate for the cell-based therapy of various diseases, such as cardiovascular diseases (Faiella \& Atoui, 2016), diabetic nephropathy (Liu \& Tang, 2016), and diverse brain injuries including stroke, neural trauma, and heatstroke (Hsuan et al, 2016).
MSCs are non-hematopoietic, multipotent cells that are present in adult marrow. They are capable of self-renewal and multilineal differentiation into various tissues of mesodermal origin, such as bone, cartilage, tendon, fat, heart, muscle, and marrow stroma (Pittenger et al., 1999); (Deans \& Moseley, 2000). hMSCs show several superior properties for therapeutic use compared to other types of stem cells. For successful cell-based therapies with hMSCs, a substantial number of cells are needed, requiring extensive ex vivo cell expansion. Owing to prolonged ex vivo expansion needed in the clinic to obtain a sufficient number of cells for therapy, long-term culture will likely evoke continuous changes in hMSCs, including cellular senescence

\footnotetext{
Manuscript received December 22, 2016, Received in revised form December 28, 2016, Accepted January 2, 2017

${ }^{\dagger}$ Corresponding Author : Jeong-Soo Park, Ph.D., Department of Biochemistry, College of Medicine, Dankook University, 119, Dandaero, Dongnam-gu, Cheonan-si, Chungcheongnam-do, 330-714, South Korea. Tel: +82-41-550-3876, Fax: +82-41-559-7940, E mail: jeongsp@dankook.ac.kr

This is an Open Access article distributed under the terms of the Creative Commons Attribution Non-Commercial License (http:// creativecommons.org/licenses/by-nc/3.0) which permits unrestricted non-commercial use, distribution, and reproduction in any medium, provided the original work is properly cited.
} 
(Yang et al., 2012); (Park et al., 2005). Considering the strengths and weaknesses of hMSCs in ex vivo cultures would provide us with some novel approaches for overcoming limitations to their therapeutic efficacy and maximize their clinical value.

\section{Advantages of MSCs over Other Stem Cell Types in Clinical Applications}

Among various stem cell types, hMSCs show several superior properties for clinical use in cell-based therapies. The benefits and limitations of each stem cell type are discussed and summarized in Table 1.

Embryonic stem cells (ESCs) are produced in the inner cell mass of the blastocyst during mammalian embryonic development, late in the first week after fertilization (Evans \& Kaufman, 1981); (Boyle et al., 2006). They are considered pluripotent, and can give rise to the three embryonic germ cell layers, and almost all types of cells found in an organism. Because of their pluripotency, they have attracted much attention. Some pluripotent human
ESC lines are established by using cells obtained from the inner cell mass of an early-stage human embryo (Thomson et al., 1998). Many protocols have been established for the differentiation of human ESCs into numerous mature and functional types of cells (Lee et al., 2007). Nevertheless, broad clinical application of ESCs remains controversial owing to concerns about teratoma formation and ethical issues raised from the embryonic source of the tissues (Wang et al., 2016).

Ethical controversies regarding ESCs led to the development of induced pluripotent stem cells (iPSCs), this development was recognized by Nobel Prize in Medicine in 2012, only six years after its initial publication. iPSCs were first reprogrammed from terminally differentiated fibroblasts by the transduction of four defined transcription factors, such as Oct3/4, Sox2, c-Myc and Klf4 or Nanog or Lin28 (Takahashi \& Yamanaka, 2006); (Takahashi et al., 2007); (Zhang et al., 2016). Like ESCs, iPSC also show great pluripotency. Recently, several promising protocols have been developed for differentiating human iPSCs into

Table 1. Advantages and disadvantages of various stem cells for cell-based therapy

\begin{tabular}{|c|c|c|}
\hline Cell type & Advantage & Disadvantage \\
\hline MSC & $\begin{array}{l}\text { Availability } \\
\text { Easy to isolate and expand } \\
\text { Multilineal differentiation } \\
\text { Immunosuppressive } \\
\text { Both of the autograft and allograft are possible } \\
\text { Free from ethical issues } \\
\text { Limited replicative lifespan } \\
\text { (safe from malignant formation) }\end{array}$ & $\begin{array}{l}\text { Limited replicative lifespan } \\
\text { (alteration of various functions including } \\
\text { multipotency) }\end{array}$ \\
\hline ESC & Pluripotent (can differentiate into almost all types of cells) & $\begin{array}{l}\text { Ethical / political issues } \\
\text { Risk of teratoma formation after trans- } \\
\text { plantation }\end{array}$ \\
\hline iPSC & $\begin{array}{l}\text { Pluripotent as ESCs } \\
\text { Can be derived from somatic cells }\end{array}$ & $\begin{array}{l}\text { Risk of teratoma formation after trans- } \\
\text { plantation }\end{array}$ \\
\hline
\end{tabular}

MSC: mesenchymal stem cell; ESC: embryonic stem cell; iPSC: induced pluripotent stem cell.

2 Dev. Reprod. Vol. 21, No. 1 March, 2017 
various types of cells (Tian et al., 2015); (Xia et al., 2013); (Carpenter et al., 2012). Even though iPSCs are attractive candidates for cell-based therapy, their use is limited by the associated risk of teratoma formation after transplantation, which is also a concern in ESC applications. Genomic instabilities and epigenetic variations of iPSs, such as aneuploidy (Amps et al., 2011), subchromosomal copy number variations (Laurent et al., 2011); (Martins-Taylor et al., 2011); (Mayshar et al., 2010), single nucleotide variations (Cheung et al., 2011); (Young et al., 2012), variations in X Chromosome inactivation (Wutz et al., 2012), and aberrant DNA methylation (Nazor et al., 2012), have been reported. These variations exist between iPSC lines, between iPSC and ESC lines, between different passages of the same iPSC lines, and even between different populations at a specific passage of the same iPSC line. Such variations potentially affect the properties of iPSCs and undermine their utility in cell-based regenerative medicine (Liang \& Zhang, 2013).

MSCs afford several advantages for clinical use, such as availability and ease of harvesting; multilineal differentiation potential; potent immunosuppressive effects; safety without any possibility of malignant transformation after infusion of allogeneic cells, which is common in the case of ESCs and iPSCs; and the lack of ethical issues that occur with the application of human ESCs. One of the most promising benefits of MSCs for cell-based therapy is their availability and ease of harvesting. MSCs can be isolated and expanded from the stroma of virtually all organs such as bone morrow, adipose tissue (Zuk et al., 2002), umbilical cord blood (Romanov et al., 2003), peripheral blood (Chong et al., 2012), amniotic fluid (In 't Anker et al., 2003) and placenta (In 't Anker et al., 2004). The most preferred and abundant sources are bone marrow and subcutaneous adipose tissue (Crisan et al., 2008); (Turinetto et al., 2016). Upon isolation, hMSCs are characterized by their ability to adhere to the surface of plastic plates and fibroblast-like morphology. Their overall isolation procedure is relatively simple compared to that for other types of stem cells (Pittenger et al., 1999). Isolated and expanded ex vivo cells can be differentiated into osteocytes, chondrocytes, adipocytes, myocytes, and marrow stroma (Pittenger \& Martin, 2004). Another characteristics of hMSCs that contributes to their therapeutic effect is that they secrete various soluble growth factors and cytokines that act in endocrine and paracrine fashions, in turn affecting their therapeutic effect (Monsel et al., 2015).

Rodent and human MSCs are advantageous owing to their immunomodulatory characteristics in both in vitro and in vivo transplant models, allowing them to act as a universal reserve of donor cells (Atoui \& Chiu, 2012). MSCs' unique immunotolerant phenotype is due to their special distribution of surface markers that allows them to escape detection from immune cells. They possess low levels of MHC class I, CD40, CD80, and CD86, with no MHC class II molecules (Pittenger et al., 1999); (LeBlanc et al., 2003); (Faiella \& Atoui, 2016). This immunomodulatory phenotype of MSCs permits the potential to use allogeneic cells for patients.

MSCs have limited ability to proliferate in cultures. Senescence activations were observed in hMSCs from different sources, such as bone marrow (Park et al., 2005); (Minieri et al, 2015), dental pulp (Muthna et al., 2010), cord blood (Ko et al., 2012), and endometrium (Burova et al., 2013). The limited replicative lifespan of MSCs guarantees safety from the threat of malignant transformation after transplantation. However, this limited cell lifespan can be a double-edged sword for clinical applications of hMSCs, as discussed later.

Fig. 1 summarizes all the advantageous characteristics of hMSCs.

\section{Prerequisites for Successful Cell Therapy with MSCs}




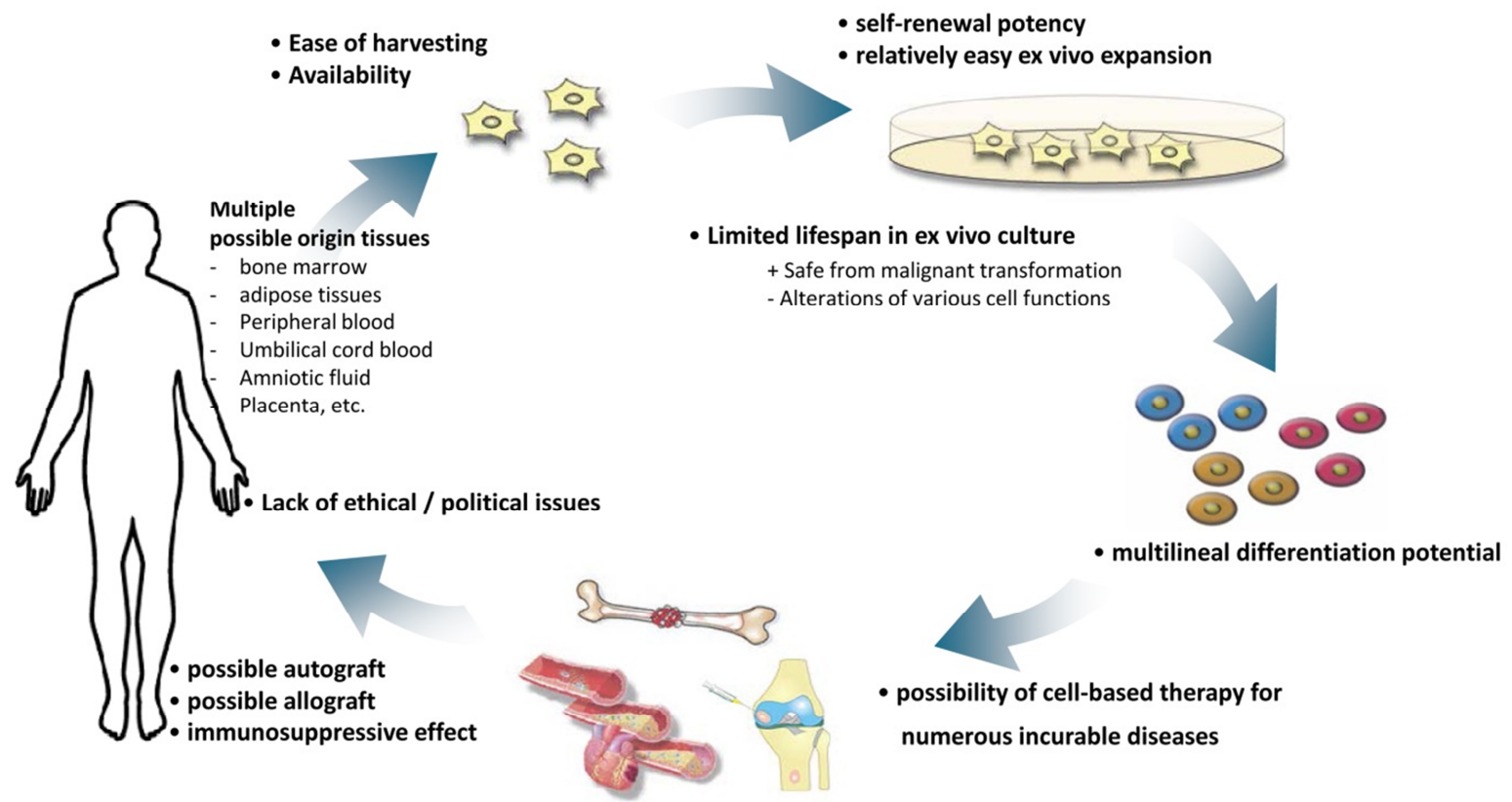

Fig. 1. Advantages of human mesenchymal stem cells in cell-based therapy. hMSCs have several advantages for clinical use, such as the availability and ease of harvesting, multilineal differentiation potential, potent immunosuppressive effects, safety without any possibility of malignant transformation after infusion of allogeneic cells which is common in the case of ESCs and iPSCs, and the lack of ethical issues that occur with the application of human ESCs. Limited lifespan of MSCs can guarantee the safe from malignancy, but can alter various cell functions including proliferation, differentiation and migration abilities that can limit the clinical usage. To expand the lifespan of hMSCs and maximize their clinical usefulness by improving their performance, various trials are under investigation.

For successful cell-based therapies, stem cells must be able to differentiate into specific targeting cells, or must act via paracrine mechanisms. Their extraction and isolation must be feasible and transplantation into humans must be safe and effective. Furthermore, to maximize the therapeutic effects of cell-based therapy, a substantial number of cells is essential, requiring extensive ex vivo cell expansion for most cell types (Faiella \& Atoui, 2016). The use of hMSCs in regenerative medicine strategies based on cell therapy relies on the ability of MSCs to proliferate readily and produce differentiated cells that can substitute for the targeting affected tissue. Therefore, it should be considered whether, after the ex vivo expansion necessary before their therapeutic use and transplantation, these cells still possess the properties of stem cells namely, self-renewal and multilineal differentiation.

\section{Factors that Limit the Stemness of MSCs: Cellular Senescence}

Although MSCs have been widely applied in cell-based therapy, their clinical usefulness remains limited. MSCs from different donors are heterogeneous. Cell passages and culture conditions in vitro affect the cell phenotype (Liu and Tang, 2016); (Turinetto et al., 2016); (Kretlow et al., 2008). Furthermore, MSC's cellular senescence significantly impairs their proliferation and differentiation potential (Park et al., 2005); (Turinetto et al., 2016). Aging af- 
fects the cell subpopulation dynamics and diminishes the function of MSCs (Duscher et al., 2014); (Wang \& Ren, 2014). The use of hMSCs is expected to be useful for treating degenerative diseases in elderly populations; however, the limited potential of the MSCs of aged patients can limit the efficacy of an autologous cell-based therapeutic approach.

Cellular senescence aggravates various functions of hMSCs. With senescence, hMSCs show decreased differentiation potential and altered commitment between osteogenic and adipogenic lineage determination, although the direction of this shift remains controversial. Some studies reported that the osteogenic activity of hMSCs were reduced according to their ex vivo culture (Banfi et al., 2000). On the other hand, the osteogenic potential of senescent hMSCs remained the same or even increased in some studies (Wagner et al., 2008); (Bruder et al., 1997); (Digirolamo et al., 1999). Some studies reported that senescent hMSCs reveal the impaired balance between osteogenic differentiation to the osteogenic versus adipogenic lineages (Kim et al., 2012).

The altered immunoregulatory activities of hMSCs during cellular senescence also influence the therapeutic potentials of cells (Sepulveda et al., 2014). Studies related to the altered immunomodulatory functions of senescent hMSCs strongly support the idea that in vivo administration of senescent hMSCs could evoke an inflammatory response at a systemic level and lead to sepsis (Turinetto et al., 2016).

Proper cell migration toward relevant stimuli is also an essential factor for the functional engraftment of hMSCs into diseased loci. Another study demonstrated altered cell migration due to changes in MSC surface markers during prolonged cultivation, which can diminish the homing ability of hMSCs (Jung et al., 2011).

Despite arrested growth upon senescence being a potent tumor suppressor mechanism, which can protect hMSCs from malignant transformation after transplantation, para- doxically, senescence itself can affect the paracrine factors secreted from cells to evoke the tumor-promoting function (Liu et al., 2007). These studies suggest that the senescence of hMSCs increases the complexity of paracrine communication among cells and further enhances their detrimental tumor-promoting effect.

\section{Trials to Overcome Senescence of MSCs}

Various approaches have been tested to expand the lifespan of hMSCs and maximize their clinical usefulness by improving their performance.

The ectopic expression of telomerase in hMSCs is one way to combat the replicative senescence of cells (Park et al., 2008); (Tang et al., 2013). However, this approach can be dangerous owing to the possibility of malignant transformation of cells. Therefore, gene engineering of telomerase in hMSCs should be avoided in clinical applications.

Allopathic treatments to solve the phenotype of senescence in hMSCs may also be employed. The decreased expression of histone deacetylases is one of the phenotypes of senescent MSCs; therefore, the use of a histone acetyltransferase inhibitor prevents the replicative senescence of MSCs (Jung et al., 2010). Additionally, rapamycin has been shown to reverse the senescent phenotype and improve immunoregulation (Gu et al., 2016).

Cellular senescence can be reduced by modulating the oxidative stress level because oxidative stress is one of the main causes of senescence. Various attempts have been made to reduce oxidative stress during the in vitro culture of hMSCs. Some studies suggested that MSCs cultured under hypoxic conditions during in vitro culture can escape from senescence and show prolonged lifespan (Fahrer et al., 2007); (Jin et al., 2010). Antioxidants can be another effective and safe alternative to overcome the senescence of hMSCs. Reducing oxidative stresses by adding antioxidants, such as ascorbic acids or $\mathrm{N}$-acetylcysteine has been shown to prolong the replicative lifespan of human 
cells including hMSCs in vitro (Kashino et al., 2003); (Lin et al., 2005).

A separate attempt to maintain hMSC's potential for self-renewal and differentiation by modifying the medium compositions showed limited success (Gharibi and Hughes, 2012). Medium supplementation with fibroblast growth factor-2, platelet-derived growth factor-BB, ascorbic acid, and epidermal growth factor increased the proliferation potential of cells and increased their lifespan. However, the differentiation potential could not be maintained with medium supplementation (Gharibi and Hughes, 2012).

Many trials are currently aiming to overcome the limited lifespan of hMSCs. This limitation is a double-edged sword for clinical applications. On the one hand, it solves the problem of malignancy; on the other hand, it limits various functions that mitigate the therapeutic effect, including self-renewal, multi-potency, migration, and immunomodulatory functions. Despite the need for more studies to improve the conditions of ex vivo expansion of cells, hMSCs are still considered a safe and effective source for cell-based therapy for numerous diseases.

\section{ACKNOWLEDGEMENTS}

This research was supported by Mid-career Researcher Program (2016R1A2B1014960) and Basic Science Research Program (2011-0014698) through the National Research Foundation of Korea (NRF) grant funded by the Ministry of Education, Science and Technology (MEST).

\section{REFERENCES}

Amps K, Andrews PW, Anyfantis G, Armstrong L, Avery S, Baharvand H, Baker J, Baker D, Munoz MB, Beil S, International Stem Cell Initiative, et al. (2011) Screening ethnically diverse human embryonic stem cells identifies a chromosome 20 minimal amplicon conferring growth advantage. Nat Biotechnol 29:1132-1144.
Atoui R, Chiu RC (2012) Mesenchymal stromal cells as universal donor cells. Expert Opin Biol Ther 12:12931297.

Banfi A, Muraglia A, Dozin B, Mastrogiacomo M, Cancedda R, Quarto R (2000) Proliferation kinetics and differentiation potential of ex vivo expanded human bone marrow stromal cells: Implications for their use in cell therapy. Exp Hematol 28:707-715.

Boyle AJ, Schulman SP, Hare JM, Oettgen P (2006) Is stem cell therapy ready for patients? Stem cell therapy for cardiac repair. ready for the next step. Circulation 114:339-352.

Bruder SP, Jaiswal N, Haynesworth SE (1997) Growth kinetics, self-renewal, and the osteogenic potential of purified human mesenchymal stem cells during extensive subcultivation and following cryopreservation. $\mathrm{J}$ Cell Biochem 64:278-294.

Burova E, Borodkina A, Shatrova A, Nokolsky N (2013) Sublethal oxidative stress induces the premature senescence of human mesenchymal stem cells derived from endometrium. Oxid Med Cell Longev 2013:474931.

Carpenter L, Carr C, Yang CT, Stuckey DJ, Clarke K, Watt SM (2012) Efficient differentiation of human induced pluripotent stem cells generates cardiac cells that provide protection following myocardial infarction in the rat. Stem Cells Dev 21:977-986.

Cheung AY, Horvath LM, Grafodatskaya D, Pasceri P, Weksberg R, Hotta A, Carrel L, Ellis J (2011) Isolation of MECP2-null Rett Syndrome patient hiPS cells and isogenic controls through $\mathrm{X}$-chromosome inactivation. Hum Mol Genet 20:2103-2115.

Chong PP, Selvaratnam L, Abbas AA, Kamarul T (2012) Human peripheral blood derived mesenchymal stem cells demonstrate similar characteristics and chondrogenic differentiation potential to bone marrow derived mesenchymal stem cells. J Orthop Res 30:634-642.

Crisan M, Yap S, Casteilla L, Chen CW, Corselli M, Park TS, Andriolo G, Sun B, Zheng B, Zhang L, Norotte C, 
Teng PN, Traas J, Schugar R, Deasy BM, Badylak S, Buhring HJ, Giacobino JP, Lazzari L, Huard J, Péault B (2008) A perivascular origin for mesenchymal stem cells in multiple human organs. Cell Stem Cell 3:301313.

Deans RJ, Moseley AB (2000) Mesenchymal stem cells: biology and potential clinical uses. Exp Hematol 28: 875-884.

Digirolamo CM, Stokes D, Colter D, Phinney DG, Class R, Prockop DJ (1999) Propagation and senescence of human marrow stromal cells in culture: A simple colonyforming assay identifies samples with the greatest potential to propagate and differentiate. $\mathrm{Br} \mathrm{J}$ Haematol 107:275-281.

Duscher D, Rennert RC, Januszyk M, Anghel E, Maan ZN, Whittam AJ, Perez MG, Kosaraju R, Hu MS, Walmsley GG, Atashroo D, Khong S, Butte AJ, Gurtner GC (2014) Aging disrupts cell subpopulation dynamics and diminishes the function of mesenchymal stem cells. Sci Rep 4:7144.

Evans MJ, Kaufman MH (1981) Establishment in culture of pluripotential cells from mouse embryos. Nature 292: 154-156.

Fahrer C, Brunauer R, Laschober G, Unterluggauer H, Reitinger S, Kloss F, Gully C, Gassner R, Lepperdinger G (2007) Reduced oxygen tension attenuates differentiation capacity of human mesenchymal stem cells and prolongs their lifespan. Aging Cell 6:745-757.

Faiella W, Atoui R (2016) Therapeutic use of stem cells for cardiovascular disease. Clin Transl Med 5:34.

Gharibi B, Hughes FJ (2012) Effects of medium supplements on proliferation, differentiation potential, and in vitro expansion of mesenchymal stem cells. Stem Cells Transl Med 1:771-782.

Gu Z, Tan W, Ji J, Feng G, Meng Y, Da Z, Guo G, Xia Y, Zhu X, Shi G, Cheng C (2016) Rapamycin reverses the senescent phenotype and improves immunoregulation of mesenchymal stem cells from MRL/lpr mice and systemic lupus erythematosus patients through inhibition of the mTOR signaling pathway. Aging (Albany NY) 8:1102-1114.

Hsuan YC, Lin CH, Chang CP, Lin MT (2016) Mesenchymal stem cell-based treatments for stroke, neural trauma, and heatstroke. Brain Behav 6:e00526.

In 't Anker PS, Scherjon SA, Kleijburg-van der Keur C, de Groot-Swings GM, Claas FH, Fibbe WE, Kanhai HH (2004) Isolation of mesenchymal stem cells of fetal or maternal origin from human placenta. Stem Cells 22: 1338-1345.

In 't Anker PS, Scherjon SA, Kleijburg-van der Keur C, Noort WA, Claas FH, Willemze R, Fibbe WE, Kanhai HH (2003) Amniotic fluid as a novel source of mesenchymal stem cells for therapeutic transplantation. Blood 102:1548-1549.

Jin Y, Kato T, Furu M, Nasu A, Kajita Y, Mitsui H, Ueda M, Aoyama T, Nakayama T, Nakamura T, Toguchida J (2010) Mesenchymal stem cells cultured under hypoxia escape from senescence via down-regulation of p16 and extracellular signal regulated kinase. Biochem Biophys Res Commun 391:1471-1476.

Jung EM, Kwon O, Kwon KS, Cho YS, Rhee SK, Min JK, Oh DB (2011) Evidences for correlation between the reduced VCAM-1 expression and hyaluronan synthesis during cellular senescence of human mesenchymal stem cells. Biochem Biophys Res Commun 404:463469.

Jung JW, Lee S, Seo MS, Park SB, Kurtz A, Kang SK, Kang KS (2010) Histone deacetylase controls adult stem cell aging by balancing the expression of polycomb genes and jumonji domain containing 3. Cell Mol Life Sci 67:1165-1176.

Kashino G, Kodama S, Nakayama Y, Suzuki K, Rukase K, Goto M, Watanabe M (2003) Relief of oxidative stress by ascorbic acid delays cellular senescence of normal 
human and Werner syndrome fibroblast cells. Free Radic Biol Med 35:438-443.

Kim M, Kim C, Choi YS, Park C, Suh Y (2012) Agerelated alterations in mesenchymal stem cells related to shift in differentiation from osteogenic to adipogenic potential: Implication to age-associated bone diseases and defects. Mech Ageing Dev 133:215-225.

Ko E, Lee KY, Hwang DS (2012) Human umbilical cord blood-derived mesenchymal stem cells undergo cellular senescence in response to oxidative stress. Stem Cells Dev 21:1877-1886.

Kretlow JD, Jin YQ, Liu W, Zhang WJ, Hong TH, Zhou G, Baggett LS, Mikos AG, Cao Y (2008) Donor age and cell passage affects differentiation potential of murine bone marrow-derived stem cells. BMC Cell Biol 9:60.

Laurent LC, Ulitsky I, Slavin I, Tran H, Schork A, Morey R, Lynch C, Harness JV, Lee S, Barrero MJ, Ku S, Martynova M, Semechkin R, Galat V, Gottesfeld J, Izpisua Belmonte JC, Murry C, Keirstead HS, Park HS, Schmidt U, Laslett AL, Muller FJ, Nievergelt CM, Shamir R, Loring JF (2011) Dynamic changes in the copy number of pluripotency and cell proliferation genes in human ESCs and iPSCs during reprogramming and time in culture. Cell Stem Cell 8:106-118.

LeBlanc KT, Tammik C, Rosendahl K, Zetterberg E, Ringden O (2003) HLA expression and immunologic properties of differentiated and undifferentiated mesenchymal stem cells. Exp Hematol 31:890-896.

Lee H, Shamy GA, Elkabetz Y, Schofield CM, Harrsion NL, Panagiotakos G, Socci ND, Tabar V, Studer L (2007) Directed differentiation and transplantation of human embryonic stem cell-derived motoneurons. Stem Cells 25:1931-1939.

Liang G, Zhang Y (2013) Genetic and epigenetic variations in iPSCs: potential causes and implications for application. Cell Stem Cell 13:149-159.

Limn TM, Tsai JL, Lin SD, Lai CS, Chang CC (2005) Ac- celerated growth and prolonged lifespan of adipose tissue-derived human mesenchymal stem cells in a medium using reduced calcium and antioxidants. Stem Cells Dev 14:92-102.

Liu D, Hornsby PJ (2007) Senescent human fibroblasts increase the early growth of xenograft tumors via matrix metalloproteinase secretion. Cancer Res 67:31173126.

Liu Y, Tang SC (2016) Recent progress in stem cell therapy for diabetic nephropathy. Kidney Dis 2:20-27.

Martins-Taylor K, Nisler BS, Taapken SM, Compton T, Crandall L, Montgomery KD, Lalande M, Xu RH (2011) Recurrent copy number variations in human induced pluripotent stem cells. Nat Biotechnol 29:488491.

Mayshar Y, Ben-David U, Lavon N, Biancotti JC, Yakir B, Clark AT, Plath K, Lowry WE, Benvenisty N (2010) Identification and classification of chromosomal aberrations in human induced pluripotent stem cells. Cell Stem Cell 7:521-531.

Minieri V, Saviozzi S, Gambarotta G, Lo Iacono M, Accomasso L, Cibrario Rocchietti E, Gallina C, Turinetto V, Giachino C (2015) Persistent DNA damage-induced premature senescence alters the functional features of human bone marrow mesenchymal stem cells. J Cell Mol Med 19:734-743.

Monsel A, Zhu YG, Gennal S, Hao Q, Liu J, Lee JW (2015) Preclinical evidence and ongoing clinical trials using mesenchymal stem cells. Anesthesiology 121:10991121.

Muthna D, Soukup T, Vavrova J, Mokry J, Cmielova J, Visek B, Jiroutova A, Havelek R, Suchanek J, Filip S, English D, Rezacova M (2010) Irradiation of adult human dental pulp stem cells provokes activation of p53, cell cycle arrest, and senescence but not apoptosis. Stem Cells Dev 19:1855-1862.

Nazor KL, Altun G, Lynch C, Tran H, Harness JV, Slavin I, 
Garitaonandia I, Müller FJ, Wang YC, Boscolo FS, Fakunle E, Dumevska B, Lee S, Park HS, Olee T, D'Lima DD, Semechkin R, Parast MM, Galat V, Laslett AL, Schmidt U, Keirstead HS, Loring JF, Laurent LC (2012) Recurrent variations in DNA methylation in human pluripotent stem cells and their differentiated derivatives. Cell Stem Cell 10:620-634.

Park IH, Zhao R, West JA, Yabuuchi A, Huo H, Ince TA, Lerou PH, Lensch MW, Daley GQ (2008) Reprogramming of human somatic cells to pluripotency with defined factors. Nature 451:141-146.

Park JS, Kim HY, Kim HW, Chae GN, Oh HT, Park JY, Shim H, Seo M, Shin EY, Kim EG, Park SC, Kwak SJ (2005) Increased caveolin-1, a cause for the declined adipogenic potential of senescent human mesenchymal stem cells. Mech Ageing Dev 126:551-559.

Pati S, Muthuraju S, Hadi RA, Huat TJ, Singh S, MaleticSavatic M, Abdullah JM, Jaafar H (2016) Neurogenic plasticity of mesenchymal stem cell, an alluring cellular replacement for traumatic brain injury. Curr Stem Cell Res Ther 11:149-157.

Pittenger MF, Mackay AM, Beck SC, Jaiswal RK, Douglas R, Mosca JD, Moorman MA, Simonetti DW, Craig S, Marshak DR (1999) Multilineage potential of adult human mesenchymal stem cells. Science 284:143-147.

Pittenger MF, Martin BJ (2004) Mesenchymal stem cells and their potential as cardiac therapeutics. Cir Res 95:9-20.

Romanov YA, Svintsitskaya VA, Smirnov VN (2003) Searching for alternative sources of post-natal human mesenchymal stem cells: candidate MSC-like cells from umbilical cord. Stem Cells 21:105-110.

Sepulveda JC, Tome M, Fernandez ME, Delgado M, Campisi J, Bernad A, Gonzalez MA (2014) Cell Senescence abrogates the therapeutic potential of human mesenchymal stem cells in the lethal endotoxemia model. Stem Cells 32:1865-1877.
Takahashi K, Yamanaka S (2006) Induction of pluripotent stem cells from mouse embryonic and adult fibroblast cultures by defined factors. Cell 126:663-676.

Tang H, Xiang Y, Jiang X, Ke Y, Xiao Z, Guo Y, Wang Q, Du M, Qin L, Zou Y, Cai Y, Chen Z, Xu R (2013) Dual expression of hTERT and VEGF prolongs life span and enhances angiogenic ability of aged BMSCs. Biochem Biophys Res Commun 440:502-508.

Thomson JA, Itskovitz-Eldor J, Shapiro SS, Waknitz MA, Swiergiel JJ, Marshall VS, Jones JM (1998) Embryonic stem cell lines derived from human blastocysts. Science 282:1145-1147.

Tian S, Liu Q, Gnatoxskiy L, Ma PX, Wang Z (2015) Heart regeneration with embryonic cardiac progenitor cells and cardiac tissue engineering. J Stem Cell Transplant Biol 1:104-129.

Turinetto V, Vitale E, Giachino C (2016) Senescence in human mesenchymal stem cells: Functional changes and implications in stem cell-based therapy. Int $\mathrm{J}$ Mol Sci 17:E1164.

Wagner W, Horn P, Castoldi M, Diehlmann A, Bork S, Saffrich R, Benes V, Blake J, Pfister S, Eckstein V, Ho AD (2008) Replicative senescence of mesenchymal stem cells: a continuous and organized process. PLoS One 3:e2213.

Wang SS, Ren J (2014) Aging as an essential modifier for the efficacy in mesenchymal stem cell therapy through an inositol phosphate 6 kinase-inositolo pyrophosphate 7-dependent mechanism. Stem Cell Res 5:43.

Wang Y, Han ZB, Song YP, Han ZC (2012) Safety of mesenchymal stem cells for clinical application. Stem Cells Int 2012:652034.

Wutz A (2012) Epigenetic alterations in human pluripotent stem cells: a tale of two cultures. Cell Stem Cell 11:915.

Xia Y, Nivet E, Sancho-Martinez I, Gallegos T, Suzuki K, Okamura D, Wu MZ, Dubova I, Esteban CR, Montser- 
rat N, Campistol JM, Izpisua Belmonte JC (2013) Directed differentiation of human pluripotent cells to ureteric bud kidney progenitor-like cells. Nat Cell Biol 15: 1507-1515.

Young MA, Larson DE, Sun CW, George DR, Ding L, Miller CA, Lin L, Pawlik KM, Chen K, Fan X, Schmidt H, Kalicki-Veizer J, Cook LL, Swift GW, Demeter RT, Wendl MC, Sands MS, Mardis ER, Wilson RK, Townes TM, Ley TJ (2012) Background mutations in parental cells account for most of the genetic heterogeneity of induced pluripotent stem cells. Cell Stem Cell 10:570-582.
Zhang J, Ratanasirintrawoot S, Chandrasekaran S, Wu Z, Ficarro SB, Yu C, Ross CA, Cacchiarelli D, Xia Q, Seligson M, Shinoda G, Xie W, Cahan P, Wang L, Ng SC, Tintara S, Trapnell C, Onder T, Loh YH, Mikkelsen T, Sliz P, Teitell MA, Asara JM, Marto JA, Li H, Collins JJ, Daley GQ (2016) LIN28 Regulates stem cell metabolism and conversion to primed pluripotency. Cell Stem Cell 19:66-80.

Zuk PA, Zhu M, Ashjian P, De Ugarte DA, Huang JI, Mizuno H, Alfonso ZC, Fraser JK, Benhaim P, Hedrick MH (2002) Human adipose tissue is a source of multipotent stem cells. Mol Biol Cell 13:4279-4295. 